\title{
Antimalarial properties of crude extracts of seeds of Brucea antidysenterica and leaves of Ocimum lamiifolium
}

\author{
Atetetgeb Kefe ${ }^{1}$, Mirutse Giday ${ }^{2 *}$, Hassen Mamo ${ }^{1}$ and Berhanu Erko ${ }^{2}$
}

\begin{abstract}
Background: The search for new antimalarial drugs has become increasingly urgent due to plasmodial resistance to existing drugs. As part of this global effort, the present study aimed at evaluating the antimalarial activity of two traditionally used medicinal plants against the disease.

Methods: Acute toxicity and four-day suppressive effects of aqueous, methanol and chloroform extracts of the seed and leaf of Brucea antidysenterica and Ocimum lamiifolium, respectively, were investigated in Swiss albino mice using Plasmodium berghei using standard procedures.

Results: Methanol extract of the leaves of $O$. lamiifolium did not exhibit any sign of acute toxicity up to the dose of $2000 \mathrm{mg} / \mathrm{kg}$ body weight. However, all mice provided with seeds of B. antidesenterica at a dose of $2000 \mathrm{mg} / \mathrm{kg}$ body died within $24 \mathrm{~h}$. The aqueous, methanol and chloroform crude extracts of $B$. antidesenterica significantly $(p<$ 0.05) inhibited parasitaemia in a dose-dependent manner and prevented body weight loss at doses of 200, 400 and $600 \mathrm{mg} / \mathrm{kg}$ body weight. In addition, the extracts prolonged the mean survival time of $P$. berghei-infected mice compared to the non-treated control. However, it did not prevent reduction in packed cell volume except the chloroform extract in three doses and methanol extract at $200 \mathrm{mg} / \mathrm{kg}$ and $400 \mathrm{mg} / \mathrm{kg}$. Extracts from O. lamiifolium also exhibited significant $(p<0.05)$ antiplasmodial activities. The extracts did not prevent body weight loss and PCV reduction, especially in chloroform. The highest suppression was recorded from aqueous crude extract of $O$. lamiifolium with $35.53 \%$ in the dose of $600 \mathrm{mg} / \mathrm{kg}$. On the other hand, a similar higher suppression was found in both methanol and chloroform of crude extracts of B. antidesenterica with $47.70 \%, 46.44 \%$ of chemosuppression, respectively, in its highest dose tested.
\end{abstract}

Conclusion: Crude aqueous, methanol and chloroform extracts of the two medicinal plants possess acceptable antimalarial effects. However, further investigation should be pursued on toxicity study and to isolate the bioactive components responsible for the observed antimalarial action of the plants.

Keywords: Malaria, Plasmodium berghei, Brucea antidysenterica, Ocimum lamiifolium, Ethiopia

\section{Background}

Malaria has been a great challenge to humanity since time immemorial. An estimated 300-500 million people are affected by malaria throughout the world annually [1]. This same world health organization (WHO) source indicates that $95 \%$ of malaria-related deaths occur in sub-Saharan Africa, with children younger than five

\footnotetext{
* Correspondence: mirutseg@yahoo.com

${ }^{2}$ Aklilu Lemma Institute of Pathobiology, Addis Ababa University, P. O. Box

1176, Addis Ababa, Ethiopia

Full list of author information is available at the end of the article
}

years of age and pregnant women being the most severely affected. In recent years, the burden of malaria has fallen in many parts of Africa following the introduction of more effective treatments and the scale-up of long-lasting insecticidal nets (LLIN) use [2]. But, vector mosquito resistance to insecticides recommended for current use [3] coupled with emergence of drugresistant parasite strains to the latest antimalarials in use [4-6] demand for new drugs with new modes of action.

Plants have been used in the traditional treatment of malaria for years in the past and present in various parts 
of the world [7] apart from being source of various antimalarial drugs [8]. In Ethiopia it is estimated that about $90 \%$ of the population is dependent on traditional medicine, essentially plants [9].

Ocimum lamiifloium Hochst. ex Benth and Brucea antidysenterica Mill are among the most common traditional medicinal plants used in Ethiopia. O. lamiifolium belongs to the family Lamiaceae. It is traditionally used to relieve pain, wound, fever, malaria and inflammatory disorders in Ethiopia [10]. It is also used for treatment of intestinal disorders, eye disease and cough [11]. Brucea antidysenterica (Simaroubaceae) is similarly used in traditional medicine for multiple purposes. Different parts of the plant are widely used against malaria, helminthic infections, fever, dysentery and other disorders $[11,12]$. Despite its wide application in the traditional healthcare domain only few organized and thorough scientific investigations have been undertaken to evaluate the safety and efficacy of Ethiopian traditional medicinal plants. In vivo and in vitro studies conducted on fruit extracts of Brucea javanica, a species closely related to Brucea antidysenterica, demonstrated antiplasmodial activity of the plant attributable to quassinoid constituents [13]. Study also shows that the organic leaf extract of Ocimum gratissimum, a species found under the genus where Ocimum lamiifolium belongs, suppressed parasitaemia of Plasmodium berghei in mice by $88.07 \%$ at a dose of $100 \mathrm{mg} / \mathrm{Kg}$ body weight [14]. Essential oil of Ocimum gratissimum demonstrated significant antimalarial activities in the four-day suppressive in vivo test in mice [15]. In vitro test conducted on three quinones isolated from Ocimum basilicum, another related species, showed antiplamodial activity with an IC50 value of below $1 \mu \mathrm{g} / \mathrm{ml}$ [16]. The present study, therefore, aimed at assessing the antimalarial activity of the crude extracts of the seed of $B$. antidysenterica and leaf of O. lamifolium against $P$. berghei in Swiss albino mice.

\section{Methods}

\section{Plant materials and identification}

The plant samples were collected from Endeget Yfotie area (Lummamie District) in Amhara Regional State, $260 \mathrm{~km}$ northwest of Addis Ababa, Ethiopia, in October, 2013. The plants were identified by Dr Mirutse Giday (second author) at Aklilu Lemma Institute of Pathobiology, Addis Ababa University, and voucher specimens were deposited in the National Herbarium of Addis Ababa University with voucher number AK01 (O. lamiifolium) and AK02 (B. antidysenterica).

\section{Preparation of crude plant extracts}

The collected plant parts were air-dried at room temperature under shade, without exposure to sun light, and ground into powder using an electric mill
(IEC, 158 VDE 066, Germany). The crude extracts were prepared by a cold maceration technique [17]. The powders of plant parts (90 gm of each part) were separately mixed in $900 \mathrm{ml}$ of distilled water, chloroform and methanol in Erlenmeyer flasks and placed on a platform shaker (GFL, model 3020, Germany) of 120 revolutions per minute (rpm) for $72 \mathrm{~h}$ at room temperature. The mixtures were first filtered using muslin gauze and then passed through Whatman grade № 1 filter paper. The methanol and chloroform extracts were concentrated in a rotary evaporator (Buchi type TRE121, Switzerland) at a temperature of $45{ }^{\circ} \mathrm{C}$ and dried in water bath at $45{ }^{\circ} \mathrm{C}$. The water extracts were frozen in a refrigerator overnight and dried in a lyophilizer (CHRIST, 3660 Osterode/harz, France) to get a freeze-dried product.

\section{Experimental animals and Plasmodium parasite inoculation}

Swiss albino mice (6-8weeks) of both sexes weighing 27-36 g and chloroquine (CQ)-sensitive P. berghei strain maintained in the animal house of the Department of Microbial, Cellular and Molecular Biology, Addis Ababa University, were used for the experiment. The mice were housed in cages under standard conditions and all had free access to food (mice pellet) and water ad libitum throughout the experimental period. Good hygiene was maintained by constant cleaning and removal of feces and spilled food from cages daily. The parasite was subsequently maintained in the laboratory by serial blood passage from infected mice to the non-infected ones on a weekly basis. Blood samples taken from donor mouse with growing parasitaemia of 30-40\% were diluted with normal saline so that each $0.2 \mathrm{ml}$ of blood contained $1 \times 10^{7}$ infected erythrocytes, the standard inocula [18]. Each mouse was intraperitoneally inoculated with $0.2 \mathrm{ml}$ of diluted blood.

\section{In vivo acute toxicity test of the crude plant extracts}

The methanol extract of the two medicinal plants were evaluated for their acute toxicity in non-infected female mice. The mice were starved for 3-4 h before the experiment with only water allowed and $1-2 \mathrm{~h}$ after the administration of the extracts. In the evaluation of each extract, 20 mice were randomly divided into four groups of 5 mice per cage and were given orally increasing doses of 500, 1000 and $2000 \mathrm{mg} / \mathrm{kg}$ body weight of the plant extracts. The mice in the control group received $0.2 \mathrm{ml}$ of respective vehicle of each extract $(3 \%$ Tween $80)$. Then, the mice were observed continuously for $1 \mathrm{~h}$, intermittently for $4 \mathrm{~h}$ and a period of $24 \mathrm{~h}$ for gross behavioral changes such as rigidity, sleep, mortality and other signs of acute toxicity manifestations and were followed for 14 days [19]. 


\section{In vivo evaluation of the antimalarial activity of plant extracts}

For an in vivo evaluation of each extract, the standard four-day suppressive method was used [4]. Male mice were infected by giving inocula of about $1 \times 10^{7}$ parasites. The infected mice were randomly divided into 11 test groups (5 mice in each group); nine test groups and two control groups (each for CQ as a standard drug and $3 \%$ tween 80 as a negative control) for each plant. The test extracts were prepared in three different doses; $200 \mathrm{mg} /$ $\mathrm{kg}, 400 \mathrm{mg} / \mathrm{kg}$ and $600 \mathrm{mg} / \mathrm{kg}$ and CQ at $25 \mathrm{mg} / \mathrm{kg}$ in a volume of $0.2 \mathrm{ml}$ and vehicles at $1.4 \mathrm{ml} / \mathrm{mouse}$ in a volume of $0.2 \mathrm{ml}$. All the extracts and the drug were given through intragastric route by using standard intragastric tube to ensure safe ingestion of the extracts and the drug. Treatment was started after $3 \mathrm{~h}$ of infection on day 0 and then continuing daily as a single dose for four days (i.e. from day 0 to day 3 ). On the fifth day $\left(D_{4}\right)$, blood sample was collected from tail snip of each mouse. Thin smear was fixed with methanol and stained with $10 \%$ Giemsa solution.

The stained slides were examined under light microscope with an oil immersion objective of $100 \times$ magnification power to evaluate the percent suppression of each extract with respect to the control groups. Respective percent parasitaemia and percentage suppression were calculated using the formula given below [20, 21].

$$
\begin{gathered}
\% \text { Suppression }=\frac{\text { Parasitaemia in negative control-Parasitaemia in study group }}{\text { Parasitiaemia in negative control }} \\
\times 100 \\
\% \text { Parasitaemia }=\frac{\text { Number of infected } R B C s}{\text { Total No of } R B C s \text { examined }} \times 100
\end{gathered}
$$

\section{Determination of packed cell volume}

Packed cell volume (PCV) of each mouse was measured before infection $\left(D_{0}\right)$ and on D4 after infection. For this purpose, blood was collected from the tail of each mouse in heparinized microhaematocrit capillary tubes up to 3/ $4^{\text {th }}$ of its length. The tubes were sealed by crystal seal and placed in a microhematocrit centrifuge (Hettich haematokrit) with the sealed ends outwards. The blood was centrifuged at $12,000 \mathrm{rpm}$ for $5 \mathrm{~min}$. The volume of the total blood and the volume of erythrocytes were measured and PCV was calculated as given below [22]:

$$
P C V=\frac{\text { Volume of erythrocytes in a given volume of blood }}{\text { Total blood volume }} \times 100 \%
$$

\section{Determination of body weight}

The body weight of each mouse in all the groups was measured on D0 and on D4 in case of treatment to evaluate the effectiveness of the extracts in preventing loss of body weight due to the parasite. Each mouse was weighted before and after the different doses using sensitive digital weighing balance (Scientech balance).

\section{Determination of mean survival time}

Mortality of both the treatment and control groups were monitored and recorded daily for each mouse for one month. The mean survival time (MST) for each group was calculated using the following formula as described below [22].

$$
M S T=\frac{\text { Sum of survival time (days) of all mice in a group }}{\text { Total number of mice in that group }}
$$

\section{Data analysis}

Data were presented as mean plus or minus standard error of the mean $(M \pm S E M)$. Statistical significance was determined by one-way analysis of variance (ANOVA) and Post hoc's Scheffe test using statistical package for social sciences (SPSS) version 17 software (Chicago, IL, USA). Student's paired t - test was used to compare parameters within groups. For all the data obtained, statistical significance was set at $p<0.05$.

\section{Results}

\section{Extraction yields of plant materials}

For seeds of Brucea antidysenterica, the highest yield was obtained for their methanol extract (8.69 g), followed by that for aqueous $(5.64 \mathrm{~g})$ and chloroform $(4.79 \mathrm{~g})$ extracts. For leaves of Ocimum lamiifolium, the highest yield was obtained for their methanol extract $(7.79 \mathrm{~g})$, followed by that for aqueous $(6.20 \mathrm{~g})$ and chloroform (5.21 g) extracts. However, there was no significant difference $(p>0.05)$ in yield among the different extracts.

\section{In vivo acute toxicity test}

The methanol extracts of the leaves of O. lamiifolium administered orally in a single dose of up to $2000 \mathrm{mg} / \mathrm{kg}$ body weight, showed no lethal effect within $24 \mathrm{~h}$ of observation. Gross physical and behavioral observation of the experimental mice revealed no visible signs of acute toxicity such as urination, hair erection, lacrimation, and reduction in feeding activity. In general, the mice were physically active. However, in case of the aqueous, chloroform and methanol extracts of the B. antidysenterica extract, lack of visible signs of acute toxicity and mice fatality were observed in the dose of $500 \mathrm{mg} / \mathrm{kg}$ body weight. At the level of $1000 \mathrm{mg} / \mathrm{kg}$ body weight, hair erection and sleepy activities were observed within $4 \mathrm{~h}$ although the mice became active from that time onwards. But, in the dose of $2000 \mathrm{mg} / \mathrm{kg}$ body weight all mice were dead within $24 \mathrm{~h}$. 


\section{In vivo evaluation of the antimalarial activity of plant extracts \\ Effect of crude extracts on PCV and body weight}

The result showed a significant $(p<0.05)$ reduction in packed cell volume (PCV) values between D0 (inoculation day) and D4 (5 days after D0) in mice treated with chloroform and methnol extracts of the leaves of $O$. lamiifolium at all the three dose levels $(200 \mathrm{mg} / \mathrm{kg}$, $400 \mathrm{mg} / \mathrm{kg}$ for chloroform and $600 \mathrm{mg} / \mathrm{kg}$ ). Whereas, mice treated with aqueous extract did not show significant $(p>0.05) \mathrm{PCV}$ reduction at all the three dose levels. There was significant $(P<0.05)$ change between D0 and D4 in body weight of mice treated with chloroform extracts at the three dose levels. The aqueous and methanol extracts treated mice had shown no significant $(P>$ 0.05 ) deviation in body weight between D4 and D0 (Table 1).

Extracts of the seeds of $B$. antidysenterica have significantly $(P<0.05)$ prevented loss of body weight between D0 and D4 in mice treated with methanol extract at all the three dose levels (200 mg/kg, $400 \mathrm{mg} / \mathrm{kg}$ and $600 \mathrm{mg} / \mathrm{kg}$ ) Mice treated with chloroform extract significantly $(p<0.05)$ lost body weight only at two dose levels $(200 \mathrm{mg} / \mathrm{kg}, 400 \mathrm{mg} / \mathrm{kg}$ ) and those treated with aqueous extract demonstrated significant $(P<0.05)$ body weight loss only at the dose level of $600 \mathrm{mg} / \mathrm{kg}$. Significant $(P<$ $0.05)$ reduction in $\mathrm{PCV}$ was observed at all the three dose levels in mice treated with aqueous extract. Mice treated with methanol extract showed significant $(P<$ $0.05)$ reduction in PCV only at the dose level of $600 \mathrm{mg} /$ $\mathrm{kg}$. However, no significant $(P>0.05)$ loss in $\mathrm{PCV}$ was shown between D0 and D4 in mice treated with chloroform extract at all the three dose levels (Table 2).

\section{Effect of crude extracts on parasitaemia and mean survival time}

In the four day suppressive test, all the extracts resulted in reduction of parasitaemia level significantly $(P<0.05)$ as compared to the negative control for both plants. However, the extracts did not clear the parasite completely on D4 as opposed to the positive control group (treated with $25 \mathrm{mg} / \mathrm{kg} \mathrm{CQ}$ ) which had no detectable parasitaemia on the same post infection day.

The crude aqueous, methanol and chloroform extracts of $O$. lamiifolium significantly suppressed the parasitaemia. The highest suppression was obtained for methanol $(24.95,24.57$ and $26.06 \%)$ and aqueous $(22.16,26.76$ and $35.53 \%$ ) extracts treated mice at the dose levels of $200 \mathrm{mg} / \mathrm{kg}, 400 \mathrm{mg} / \mathrm{kg}$ and $600 \mathrm{mg} / \mathrm{kg}$, respectively. The extracts also prolonged the mean survival time of infected mice compared to the non-treated ones (Table 3).

In the same way, the aqueous, methanol and chloroform extracts of $B$. antdysenterica showed significant parasite suppression in all the doses administered and they exhibited significant suppression of the parasitaemia at a higher dose $(600 \mathrm{mg} / \mathrm{kg})$. The highest suppression was obtained for methanol (38.08, 43.33 and $46.44 \%)$ and chloroform (31.23, 43.23 and $47.70 \%)$ extracts treated mice at the dose levels of $200 \mathrm{mg} / \mathrm{kg}$, $400 \mathrm{mg} / \mathrm{kg}$ and $600 \mathrm{mg} / \mathrm{kg}$, respectively. The mean survival time (MST) of mice for a given extract was also longer compared to those in the negative control (Table 4).

\section{Discussion}

The methanol extracts of the two plants produced the highest yield and this could be due to high concentration

Table 1 Effect of aqueous, methanol and chloroform crude extracts of leaves Ocimum lamiifolium on body weight and PCV of P. berghei infected mice

\begin{tabular}{|c|c|c|c|c|c|}
\hline \multirow{2}{*}{$\begin{array}{l}\text { Extracts/ } \\
\text { treatments }\end{array}$} & \multirow{2}{*}{$\begin{array}{l}\text { Dose } \\
\text { (mg/ } \\
\mathrm{kg})\end{array}$} & \multicolumn{2}{|l|}{ PCV } & \multicolumn{2}{|l|}{ Body weight } \\
\hline & & Do & $D-4$ & Do & $D-4$ \\
\hline NC & 0 & $52.80 \pm 0.48$ & $40.58 \pm 0.64^{b}$ & $27.90 \pm 0.64$ & $23.98 \pm 1.46$ \\
\hline \multirow[t]{3}{*}{$\mathrm{dH}_{2} \mathrm{O}$} & 200 & $53.59 \pm 2.88$ & $44.75 \pm 0.96^{a}$ & $27.76 \pm 0.20$ & $26.88 \pm 0.25^{a}$ \\
\hline & 400 & $55.09 \pm 1.01$ & $47.49 \pm 2.22^{a}$ & $28.12 \pm 0.13$ & $29.56 \pm 0.32^{a}$ \\
\hline & 600 & $51.98 \pm 0.99$ & $50.38 \pm 0.52^{a}$ & $26.88 \pm 0.15$ & $27.20 \pm 0.55^{a}$ \\
\hline \multirow[t]{3}{*}{$\mathrm{CH}_{3} \mathrm{OH}$} & 200 & $54.66 \pm 1.15$ & $42.67 \pm 0.67^{b}$ & $26.50 \pm 1.41$ & $26.29 \pm 2.53^{a}$ \\
\hline & 400 & $51.69 \pm 1.11$ & $40.13 \pm 1.84^{b}$ & $27.56 \pm 1.41$ & $26.22 \pm 1.40^{a}$ \\
\hline & 600 & $53.98 \pm 0.99$ & $56.09 \pm 0.44^{b}$ & $29.10 \pm 2.58$ & $30.09 \pm 2.16^{a}$ \\
\hline \multirow[t]{3}{*}{$\mathrm{CHCl}_{3}$} & 200 & $56.94 \pm 0.50$ & $46.36 \pm 0.6^{b}$ & $29.38 \pm 2.39$ & $24.36 \pm 1.44^{b}$ \\
\hline & 400 & $54.14 \pm 1.56$ & $42.30 \pm 0.87^{b}$ & $33.70 \pm 8.76$ & $28.23 \pm 6.90^{b}$ \\
\hline & 600 & $51.68 \pm 0.74$ & $43.23 \pm 0.66^{b}$ & $28.66 \pm 2.55$ & $25.00 \pm 0.51^{b}$ \\
\hline CQ & 25 & $54.73 \pm 0.27$ & $53.37 \pm 0.21^{a}$ & $28.80 \pm 0.23$ & $30.97 \pm 0.92^{b}$ \\
\hline
\end{tabular}

Key: Values are presented as mean $\pm \mathrm{SEM} ; n=5 ; \mathrm{PCV}$ packed cell volume, $\mathrm{NC}$ negative control (3\% tween 80$), d \mathrm{H}_{2} \mathrm{O}$ distilled water, $\mathrm{CH}_{3} \mathrm{OH}$ methanol, $\mathrm{CHCl}_{3}$ chloroform, $C Q$ chloroquine (positive control); ${ }^{a}=$ the difference between day 0 and day 4 is not significant $(P>0.05) ;{ }^{b}=$ the difference between day 0 and day 4 is significant $(P<0.05)$ 
Table 2 Effect of aqueous, methanol and chloroform crude extracts of seeds of Brucea antidysentmerica on body weight and PCV of P. berghei infected mice

\begin{tabular}{|c|c|c|c|c|c|}
\hline \multirow{2}{*}{$\begin{array}{l}\text { Extracts/ } \\
\text { treatments }\end{array}$} & \multirow{2}{*}{$\begin{array}{l}\text { Dose } \\
\text { (mg/ } \\
\mathrm{kg})\end{array}$} & \multicolumn{2}{|l|}{ PCV } & \multicolumn{2}{|l|}{ Body weight } \\
\hline & & D0 & D-4 & D0 & D-4 \\
\hline NC & & $53.37 \pm 0.75$ & $46.67 \pm 1.79^{b}$ & $28.70 \pm 3.24$ & $27.60 \pm 3.88$ \\
\hline \multirow[t]{3}{*}{$\mathrm{dH}_{2} \mathrm{O}$} & 200 & $56.99 \pm 2.02$ & $45.10 \pm 0.65^{b}$ & $32.25 \pm 1.22$ & $29.75 \pm 0.09^{a}$ \\
\hline & 400 & $56.84 \pm 2.83$ & $43.53 \pm 5.08^{b}$ & $31.50 \pm 0.79$ & $30.24 \pm 0.52^{a}$ \\
\hline & 600 & $55.74 \pm 1.00$ & $48.62 \pm 1.93^{b}$ & $25.80 \pm 0.89$ & $31.10 \pm 1.37^{b}$ \\
\hline \multirow[t]{3}{*}{$\mathrm{CH}_{3} \mathrm{OH}$} & 200 & $50.78 \pm 0.96$ & $51.29 \pm 0.29^{\mathrm{a}}$ & $28.56 \pm 1.41$ & $31.22 \pm 1.40^{\mathrm{b}}$ \\
\hline & 400 & $53.19 \pm 1.09$ & $53.26 \pm 2.20^{a}$ & $34.10 \pm 2.58$ & $36.09 \pm 2.16^{b}$ \\
\hline & 600 & $56.62 \pm 1.90$ & $50.40 \pm 3.55^{b}$ & $31.50 \pm 2.30$ & $33.35 \pm 1.86^{b}$ \\
\hline \multirow[t]{3}{*}{$\mathrm{CHCl}_{3}$} & 200 & $55.67 \pm 1.38$ & $52.89 \pm 1.30^{\mathrm{a}}$ & $30.95 \pm 2.25$ & $32.36 \pm 0.28^{b}$ \\
\hline & 400 & $52.09 \pm 2.83$ & $53.09 \pm 0.95^{\mathrm{a}}$ & $29.6 \pm 1.83$ & $31.25 \pm 0.44^{b}$ \\
\hline & 600 & $51.8 \pm 1.59$ & $51.27 \pm 1.95^{\mathrm{a}}$ & $29.5 \pm 1.41$ & $29.39 \pm 0.5^{\mathrm{a}}$ \\
\hline CQ & 25 & $52.27 \pm 0.74$ & $51.82 \pm 0.82^{\mathrm{a}}$ & $30.54 \pm 0.37$ & $33 \pm 0.37^{b}$ \\
\hline
\end{tabular}

Key: Values are presented as mean $\pm \mathrm{SEM} ; n=5 ; \mathrm{PCV}$ packed cell volume, $\mathrm{NC}$ negative control (3\% tween 80 ), $\mathrm{dH} 2 \mathrm{O}$ distilled water, $\mathrm{CH}_{3} \mathrm{OH}$ methanol, $\mathrm{CHCl}_{3}$ chloroform, $C Q$ chloroquine (positive control); ${ }^{a}=$ the difference between day 0 and day 4 is not significant $(P>0.05) ;{ }^{b}=$ the difference between day 0 and day 4 is significant $(P<0.05)$

of compounds in the plants that better dissolve in methanol. The highest yield of methanol extracts could also be attributed to relative ability of methanol to penetrate cellular membranes to extract ingredients in cells. The leaf extracts of Ocimum lamiifolium did not cause mortality or any sign of behavioral change that is indicative of acute toxicity in the experimental mice after oral administration of extract (500 to $2000 \mathrm{mg} / \mathrm{kg}$ body weight). Therefore, the plant can be considered safe according to the Organization for Economic Cooperation and Development (OECD) guideline which recommends a maximum dose of $2000 \mathrm{mg} / \mathrm{kg}$ for acute toxicity [19]. This could justify the common use of the plant in
Ethiopian traditional medicine to treat malaria and other ailments.

In case of methanol extract of the seeds of Brucea antidysenterica, no visible signs of acute toxicity and death of the mice were observed at a dose of $500 \mathrm{mg} / \mathrm{kg}$ body weight while at the level of $1000 \mathrm{mg} / \mathrm{kg}$ body weight hair erection and sleepy activities were observed but no death was recorded. Meanwhile, at the dose of $2000 \mathrm{mg} / \mathrm{kg}$ body weight all mice were dead. This indicates that the lethal dose $\left(\mathrm{LD}_{50}\right)$, a concentration of a chemical that kills $50 \%$ of the test animals, of B. antidysenterica methanolic extract is less than $2000 \mathrm{mg} / \mathrm{kg}$ body weight.

Table 3 Antimalarial activities of aqueous, methanol and chloroform extracts of leaves of $O$. lamiifolium and mean survival time of $P$. berghie infected mice

\begin{tabular}{|c|c|c|c|c|}
\hline \multirow{2}{*}{$\begin{array}{l}\text { Extraction } \\
\text { solvents }\end{array}$} & \multirow{2}{*}{$\begin{array}{l}\text { Dose (mg/ } \\
\mathrm{kg})\end{array}$} & \multicolumn{2}{|c|}{ Extract antimalarial activity on D4 post-infection } & \multirow[t]{2}{*}{ Mean survival time (days) } \\
\hline & & $\%$ Parasitaemia \pm SEM & \% suppression & \\
\hline \multirow[t]{3}{*}{$\mathrm{dH}_{2} \mathrm{O}$} & 200 & $35.68 \pm 1.42$ & 22.16 & $10.95 \pm 1.04^{*}$ \\
\hline & 400 & $33.57 \pm 2.81$ & 26.76 & $11.65 \pm 0.65^{*}$ \\
\hline & 600 & $29.55 \pm 0.89$ & 35.53 & $12.50 \pm 0.41^{*}$ \\
\hline \multirow[t]{3}{*}{$\mathrm{CH}_{3} \mathrm{OH}$} & 200 & $33.83 \pm 3.43$ & 24.95 & $10.00 \pm 1.70^{*}$ \\
\hline & 400 & $34.00 \pm 5.92$ & 24.57 & $12.80 \pm 0.76^{*}$ \\
\hline & 600 & $33.33 \pm 11.69$ & 26.06 & $11.00 \pm 0.80^{*}$ \\
\hline \multirow[t]{3}{*}{$\mathrm{CHCL}_{3}$} & 200 & $38.00 \pm 3.88$ & 15.70 & $9.40 \pm .67^{*}$ \\
\hline & 400 & $36.42 \pm 2.01$ & 19.21 & $9.80 \pm 0.67^{*}$ \\
\hline & 600 & $35.75 \pm 3.37$ & 20.69 & $9.60 \pm 1.51$ \\
\hline \multirow[t]{2}{*}{ Control } & CQ (25 mg) & $0.00 \pm 0.00$ & 100.00 & ND \\
\hline & T80 & $45.84 \pm 2.11$ & 0.00 & $7.00 \pm 0.50$ \\
\hline
\end{tabular}

Key: Values are presented as $\mathrm{M} \pm \mathrm{SEM} ; n=5 ; \mathrm{T} 80=$ negative control (3 \% tween 80 ); $C Q$ positive control (chloroquine), $N D$ no death within the follow-up interval (30-days), $\mathrm{dH}_{2} \mathrm{O}$ distilled water, $\mathrm{CH}_{3} \mathrm{OH}$ methanol, $\mathrm{CHCl}_{3}$ chloroform, $\mathrm{CQ}$ chloroquine (positive control); ${ }^{*}=$ values are significantly different ( $\left.p<0.05\right)$ from that of the negative control 
Table 4 Antimalarial activities of aqueous, methanol and chloroform extracts of seeds of B. antidysenterica and mean survival time of P. berghie infected mice

\begin{tabular}{|c|c|c|c|c|}
\hline \multirow[t]{2}{*}{ Extraction solvents } & \multirow{2}{*}{$\begin{array}{l}\text { B. antidysenterica } \\
\text { Dose }(\mathrm{mg} / \mathrm{kg})\end{array}$} & \multicolumn{2}{|c|}{ Extract antimalarial activity on D4 post-infection } & \multirow{2}{*}{$\begin{array}{l}\text { Mean } \\
\text { survival } \\
\text { time (days) }\end{array}$} \\
\hline & & $\%$ Parasitaemia \pm SEM & \% suppression & \\
\hline \multirow[t]{3}{*}{$\mathrm{dH}_{2} \mathrm{O}$} & 200 & $39.69 \pm 1.10$ & 24.05 & $9.25 \pm 0.69^{*}$ \\
\hline & 400 & $32.19 \pm 0.62$ & 38.40 & $10 \pm 00.54^{*}$ \\
\hline & 600 & $28.39 \pm 1.68$ & 45.68 & $12.50 \pm 0.41^{*}$ \\
\hline \multirow[t]{3}{*}{$\mathrm{CH}_{3} \mathrm{OH}$} & 200 & $34.36 \pm 0.86$ & 38.08 & $12.90 \pm 1.04$ \\
\hline & 400 & $28.57 \pm 1.31$ & 43.33 & $14.80 \pm 1.20^{*}$ \\
\hline & 600 & $27.99 \pm 0.89$ & 46.44 & $15.00 \pm 1.40^{*}$ \\
\hline \multirow[t]{3}{*}{$\mathrm{CHCl}_{3}$} & 200 & $35.94 \pm 0.86$ & 31.23 & $12.00 \pm 1.70^{*}$ \\
\hline & 400 & $29.67 \pm 1.31$ & 43.23 & $13.00 \pm 0.80^{*}$ \\
\hline & 600 & $27.33 \pm 0.89$ & 47.70 & $15.50 \pm 0.41^{*}$ \\
\hline \multirow[t]{2}{*}{ Controls } & QC (25 mg) & $0.00 \pm 0.00$ & 100.00 & ND \\
\hline & T80 & $52.26 \pm 1.50$ & 0.00 & $7.00 \pm 0.50$ \\
\hline
\end{tabular}

Key: Values are presented as $\mathrm{M} \pm \mathrm{SEM} ; n=5 ; \mathrm{T} 80=$ negative control (3\% tween 80); $C Q$ positive control (chloroquine), ND no death within the follow-up interval (30-days), $\mathrm{dH}_{2} \mathrm{O}$ distilled water, $\mathrm{CH}_{3} \mathrm{OH}$ methanol, $\mathrm{CHCl}_{3}$ chloroform, $\mathrm{CQ}$ chloroquine (positive control); ${ }^{*}=$ values are significantly different $(p<0.05)$ from that of the negative control

All the three crude extracts (aqueous, methanol and chloroform) of $B$. antidysentrica and aqueous and methanol extracts of $O$. lamiifolium prevented weight loss. However, chloroform extract of O. lamiifilum did not prevent weight loss which could be attributed to the presence of compounds that have effect on appetite.

The PCV values of $P$. berghei infected mice that were treated with the extracts of both plants were reduced as a result of malaria infection. The mean survival time of mice treated with all the extracts of $B$. antidysenterica was longer compared to the respective negative control, confirming that the crude extracts of the study plant suppressed $P$. berghei and probably reduced the overall pathogenic effect of the parasite in the study mice. However, mice treated with $O$. lamiifolium extract lived shorter. This may be due to the suppressive effects of the plant. This suggests that the crude extracts of $B$. antidysenterica were relatively more protective than that of $O$. lamiifolium. It may be because of the relatively shorter half life of $O$. lamiifolium [23].

According to Krettli et al. [24] a compound is considered active when reduction in parasitaemia is $\geq 30 \%$. In this study, all test groups treated with methanol, aqueous and chloroform crude extracts of B. antidesenterica induced more than $30 \%$ suppression including the lower doses except the $200 \mathrm{mg} / \mathrm{kg}$ of the aqueous extract. Similar studies on other plant species such as Acacia nilotica [25], Clerodendrum myricoides, Dodonea angustifolia and Aloe debrana [26] and A. africanus [27] reported significant parasitaemia suppression.

A remarkable suppression suggests the potency of the seed extracts of $B$. antidyesenterica against malaria. The antimalarial activity of the plant might be attributed to the presence of bioactive compounds such as quassinoid and canthin alkaloids [28]. However, the active compound(s) responsible for the observed activity need to be identified in future studies.

On the other hand, the lower doses $(200 \mathrm{mg} / \mathrm{kg}$ and $400 \mathrm{mg} / \mathrm{kg}$ ) of the methanol and aqueous extracts of $O$. lamiifolium may be considered to have lower antimalarial activities. This could be due to the presence of active compounds at low levels in natural products whose activity may not be detected at lower doses [24].

The difference between the antimalarial activities of extracts of both plants in all the three solvents may indicate differences in the level and composition of active compounds [29]. The difference may also be due to differences between the solvents used for the extraction of the plant materials as the secondary metabolites/compounds could be different.

The observed low antimalarial activity of plant extracts tested could be partly explained by the fact that many antimalarial traditional medicinal plants may lack direct antiplasmodial activity to cure the disease but their beneficial role could be in their antipyretic, analgestic and immune stimulatory effect as demonstrated in other studies [7, 10]. Furthermore, in traditional medicinal practice, the healers are known to prescribe concoctions made from different species of plants that might have high synergetic effects. According to Abdu et al. [30], biological actions can be due to these components in complicated concert of synergistic or antagonistic activities. Also, the effectiveness of a given extract can also be influenced by the rate of gastrointestinal uptake and the half life in plasma metabolism of the active compounds [23]. 
The extracts of the two plant parts did not totally clear the parasitaemia up to the highest tested doses. Complete clearance of parasitaemia may be achieved within the toxic range of the extracts. These findings provide information on the antimalarial effect of the plant extracts tested and warrant carrying out of chronic toxicity studies.

The limitation of this study includes failure for not conducting additional antimalarial tests using curative and prophylactic methods.

\section{Conclusion}

This study has shown that aqueous, methanol and chloroform extracts of seeds of $B$. antiydesenterica and leaves $O$. lamiifolium exhibited a reasonable antiplasmodial activity. While O. lamiifolium was safe at the highest tested dose of the extracts, $B$. antidysenterica showed toxicity at $2000 \mathrm{mg} / \mathrm{kg}$ body weight. Further studies are recommended on antiplasmodial activities as well as safety profiles of the plants.

\section{Ethical consideration}

The study obtained ethical clearance from the Institutional Ethics Review Board of College of Natural Sciences, Addis Ababa University (No: GSR/1559/05). The mice were treated as per the guidelines on the care and use of animals for scientific purposes.

\section{Availability of data and materials}

Specimens of the two tested antimalarial plants were deposited at the National Herbarium of the Addis Ababa University with voucher numbers AK01 assigned for Ocimum lamiifolium and AK02 for Brucea antidysenterica. Data related to antimalarial in vivo tests of the two plants were deposited into a computer available at Aklilu Lemma Institute of Pathobiology, Addis Ababa University.

Competing interests

The authors declare that they have no competing interests.

\section{Authors' contributions}

MG and BE conceived the research idea. AK conducted the experiment, collected the plant specimens, analyzed and interpreted the data as well as prepared the first draft. MG identified the plants. MG, BE, HM critically read and revised the paper. All authors read and approved the paper before its final submission.

\section{Acknowledgments}

The study received financial support from School of graduate Studies through College of Natural Sciences, Addis Ababa University.

\footnotetext{
Author details

${ }^{1}$ Department of Microbial, Cellular and Molecular Biology, College of Natural Sciences, Addis Ababa University, P.O.Box 1176, Addis Ababa, Ethiopia. ${ }^{2}$ Aklilu Lemma Institute of Pathobiology, Addis Ababa University, P. O. Box 1176, Addis Ababa, Ethiopia.
}

Received: 20 August 2015 Accepted: 9 April 2016 Published online: 14 April 2016

\section{References}

1. WHO. World malaria report 2011. Geneva: World Health Organization; 2012.

2. WHO. World malaria report 2012. Geneva: World Health Organization; 2013.

3. Nkya TE, Akhouayri I, Poupardin R, Batengana B, Mosha F, Magesa S, Kisinza W, David JP. Insecticide resistance mechanisms associated with different environments in the malaria vector Anopheles gambiae: a case study in Tanzania. Malar J. 2014;13:28.

4. Fidock DA, Rosenthal PJ, Croft SL, Brun R, Nwaka S. Antimalarial drug discovery: efficacy models for compound screening. Nat Rev Drug Discov. 2004:3:509-20.

5. Ashley EA, Dhorda M, Fairhurst RM, Amaratunga C, Lim P, Suon S, et al. Spread of artemisinin resistance in Plasmodium falciparum malaria. N Engl J Med. 2014:371:411-23.

6. WHO. Malaria 2015. [www.who.int/malaria/media/artemisinin_resistance_qa/en].

7. Krettli AU, Neto $V$, Brandao M, Ferrari W. The search for new antimalarial drugs from plants used to treat fever and malaria or plants randomly selected. Mem Inst Oswald Cruz. 2001:96:1033-42.

8. Bero J, Frederich M, Quetin-Leclercq J. Antimalarial compounds isolated from plants used in traditional medicine. J Pharm Pharmacol. 2009;61: 1401-33.

9. Zelalem P. The Need of standardized herbal remedies as alternate sources of antimalarial products in Ethiopia. J Pharmacol. 2011:3:1440-7.

10. Makonnen E, Debella A, Zerihun L, Abebe D, Teka F. Antipyretic properties of the aqueous and ethanol extracts of the leaves of Ocimum suave and Ocimum lamiifolium in mice. J Ethnopharmacol. 2003:88:85-91.

11. Dawit A, Asfaw D, Kelbessa U. Medicinal plants and other useful plants of Ethiopia. Addis Ababa: Addis Ababa University Press; 2003.

12. Grace OM, Fowler DG. Brucea antidysenterica J.F. Mill. Medicinal plants/ Plantes médicinales. Wageningen: PROTA; 2008.

13. O'Neill MJ, Bray DH, Boardman P, Chan KL, Phillipson JD, Warhurst DC, Peters W. Plants as sources of antimalarial drugs, part 4: activity of Brucea javanica fruits against chloroquine-resistant Plasmodium falciparum in vitro and against Plasmodium berghei in vivo. J Nat Prod. 1987;50:41-8.

14. Murithi CK, Fidahusein DS, Nguta JW, Lukhoba CW. Antimalarial activity and in vivo toxicity of selected medicinal plants naturalised in Kenya. Int J Educ Res. 2014;2:5.

15. Tchoumbougnang F1, Zollo PH, Dagne E, Mekonnen Y. In vivo antimalarial activity of essential oils from Cymbopogon citratus and Ocimum gratissimum on mice infected with Plasmodium berghei. Planta Med. 2005;71:20-3.

16. Kayembe JS, Taba KM, Ntumba K, Tshiongo MTC, Kazadi TK. In vitro antimalarial activity of 20 quinones isolated from four plants used by traditional healers in the Democratic Republic of Congo. J Med Plants Res. 2010; 2010(4):991-4

17. O'Neill MJ, Bray DH, Boardman P, Phillipson DJ, et al. Plants as sources of antimalarial drugs: in vitro antimalarial activities somequassinoids. Antimicrob Agents Chemother. 1986;30:101-4.

18. Ogu Gl, Aisuodionoe ME, Nwachukwu P. Antiplasmodial activity of Caesalpinia Pulcherrima (Swarts) stem. IJBPAS. 2012;1:168-78.

19. OECD. OECD guideline for testing of chemicals. Acute oral toxicity-Up-anddown procedure. 2001.

20. Li QG, Si YZ, Lee P, Wong E, Xie LH, Kyle DE, Dow GS. Efficacy of comparison of intravenous artelinate and artesunate in Plasmodium berghei infected Sprangue-dawlery rats. Parasitology. 2003;126:283-91.

21. Devi CU, Atul PK, Pillal CR. Antiplasmodial effect of three medicinal plants: preliminary study. Curr Sci. 2001:80:917-9.

22. Mengistie B, Makonnen E, Urga K. In vivo antimalarial activity of Dodonaea angustifolia seed extracts against plasmodium berghei in mice model. MEJS. 2012:4:47-63.

23. Franssen FJ, Smeijsters LW, Berger I, Aldana BM. In vitro and in vivo antiplasmodial activities of some plants traditionally used in Guatemala against malaria. Antimicrob Agent Chemother. 1997;41:1500-3.

24. Krettli AU, Adebayo JO, Krettli LG. Testing of natural products and synthetic molecules aiming at new antimalarials. Curr Drug Targ. 2009;10:261-70.

25. Alli LA, Adesokan AA, Salawu OA, Akanji MA, Tijani AY. Antiplasmodial activity of aqueous root extract of Acacia nilotica. Afr J Biochem Res. 2011;5:214-9.

26. Deressa T, Mekonnen $Y$, Animut A. In vivo antimalarial activities of Clerodendrum myricoides, Dodonea angustifolia and Aloe debrana against Plasmodium berghei. Ethiop J Health Dev. 2010;24:25-9.

27. Dikasso D, Makonnen E, Debella A, Abebe D, Urga K, et al. In vivo antimalarial activity of hydroalcoholic extracts from Asparagus africanus Lam. in mice infected with Plasmodium berghei. Ethiop J Health Dev. 2006;20:112-8. 
28. Zhengming G, Suryanarayana V, Robert WS, Larry AW, Robert DS.

Biologically active quassinoids and their chemistry: potential leads for drug design. Front Med Chem. 2009;4:1-22.

29. Muregi FW, Ishain A, Suzuki T, Kino H, Amano T, Mkoji GM, Miyase T, Terada $M$, et al. In vivo antimalarial activity of aqueous extracts from Kenyan medicinal plants and their chloroquinine potentiation effects against a blood-induced CQ resistant rodent malaria parasite in mice. Phytother Rev. 2007:21:337-43.

30. Abdu KB, Khan ME, Rumah MM. Antimicrobial activity and phytochemical screening of extracts from the root bark of Carissa edulis, against human/ animal. J Trop Med. 2008;2:1-6

Submit your next manuscript to BioMed Central and we will help you at every step:

- We accept pre-submission inquiries

- Our selector tool helps you to find the most relevant journal

- We provide round the clock customer support

- Convenient online submission

- Thorough peer review

- Inclusion in PubMed and all major indexing services

- Maximum visibility for your research

Submit your manuscript at www.biomedcentral.com/submit
Biomed Central 